\title{
Characterization of Sulfolobus islandicus rod-shaped virus 2 gp19, a single-strand specific endonuclease
}

\author{
Andrew F. Gardner • David Prangishvili • \\ William E. Jack
}

Received: 21 March 2011/Accepted: 26 May 2011/Published online: 11 June 2011

(c) The Author(s) 2011. This article is published with open access at Springerlink.com

\begin{abstract}
The hyperthermophilic Sulfolobus islandicus rod-shaped virus 2 (SIRV2) encodes a 25-kDa protein (SIRV2gp19) annotated as a hypothetical protein with sequence homology to the RecB nuclease superfamily. Even though SIRV2gp19 homologs are conserved throughout the rudivirus family and presumably play a role in the viral life cycle, SIRV2gp19 has not been functionally characterized. To define the minimal requirements for activity, SIRV2gp19 was purified and tested under varying conditions. SIRV2gp19 is a single-strand specific endonuclease that requires $\mathrm{Mg}^{2+}$ for activity and is inactive on double-stranded DNA. A conserved aspartic acid in RecB nuclease superfamily Motif II (D89) is also essential for SIRV2gp19 activity and mutation to alanine (D89A) abolishes activity. Therefore, the SIRV2gp19 cleavage mechanism is similar to previously described RecB nucleases. Finally, SIRV2gp19 single-stranded DNA endonuclease activity could play a role in host chromosome degradation during SIRV2 lytic infection.
\end{abstract}

Communicated by L. Huang.

Electronic supplementary material The online version of this article (doi:10.1007/s00792-011-0385-0) contains supplementary material, which is available to authorized users.

A. F. Gardner $(\bowtie)$. W. E. Jack

New England Biolabs, Inc., 240 County Road, Ipswich, MA 01938, USA

e-mail: gardner@neb.com

D. Prangishvili

Biologie Moléculaire du Gène chez les Extrêmophiles, Institut Pasteur, 25 rue du Docteur Roux,

75724 Paris Cedex 15, France
Keywords Archaeal DNA replication - Biochemical characterization · Enzyme mechanism - Molecular biology of Archaea $\cdot$ Archaeal virus

\section{Introduction}

Sulfolobus islandicus rod-shaped virus 2 (SIRV2) infects the archeaon Sulfolobus islandicus at both extreme temperature $\left(70-80^{\circ} \mathrm{C}\right)$ and acidity $(\mathrm{pH} 3)$ and has been the focus of structural, genomic, and transcriptional studies (Blum et al. 2001; Kessler et al. 2004; Peng et al. 2001; Prangishvili et al. 2006a). The SIRV2 genome has been completely sequenced; however, the majority of open reading frames (ORFs) are annotated as hypothetical proteins that share little sequence homology to other proteins in GenBank (Blum et al. 2001; Prangishvili et al. 2006b). Thus, a key step in understanding SIRV2 biology will be assigning biochemical and biological functions to hypothetical SIRV2 proteins.

SIRV2gp19 was previously annotated as a hypothetical nuclease based on amino acid similarity to the RecB nuclease superfamily (Aravind et al. 2000; Dillingham and Kowalczykowski 2008). SIRV2gp19 homologs are conserved in related thermophilic rudiviruses including Acidianus rod-shaped virus 1 (ARV1gp17), Sulfolobus islandicus rod-shaped virus 1 (SIRV2gp12) and Stygiolobus rodshaped virus (SRV ORF199) suggesting a common function (Supplemental Figure S1). Interestingly, SIRV2gp19 shares sequence similarity with CRISPR-associated (cas4) nucleases from Sulfolobus and suggests a common ancestor (Jansen et al. 2002) (Supplemental Figure S1). SIRV2gp19 shares conserved RecB nuclease superfamily motifs including a Motif II (GxhD) aspartic acid that coordinates a divalent metal ion essential for nuclease activity, Motif III 
(hhE/DhK) lysine that interacts with a phosphate oxygen on the DNA backbone, and a cysteine-rich motif (Jansen et al. 2002; Singleton et al. 2004; Wang et al. 2000; Yu et al. 1998). To define the function of SIRV2gp19, this study examines the minimal requirements for SIRV2gp19 biochemical activity and substrate specificity and proposes a role in the SIRV2 life cycle.

\section{Materials and methods}

\section{Enzymes}

All restriction endonucleases, modifying enzymes, DNA polymerases, nucleotides, DNA ladders, and expression vectors were from New England Biolabs.

\section{Strains}

E. coli strains for cloning (NEB 5-alpha) and expression (SHuffle $^{\circledR}$ T7 Express) were from New England Biolabs.

MBP-SIRV2gp19 gene synthesis, cloning and purification

To improve protein expression, a synthetic SIRV2gp19 gene was codon optimized to reflect the codon usage of E. coli rather than the native S. islandicus. SIRV2gp19 gene was synthesized by PCR amplification of overlapping oligonucleotides (Czar et al. 2009).

To assemble a template for SIRV2gp19 gene synthesis, an equimolar amount $(1 \mu \mathrm{M})$ of each overlapping oligonucleotide (Supplementary Table S1) was combined in $1 \times$ Standard Taq Buffer (10 mM Tris-HCl, pH 8.3, $50 \mathrm{mM}$ $\mathrm{KCl}, 1.5 \mathrm{mM} \mathrm{MgCl}_{2}$ ) and then serially diluted by twofold. PCR reactions $(50 \mu \mathrm{L})$ were assembled as follows: $1 \times$ Phusion Master Mix (containing dNTPs, HF reaction buffer, and Phusion DNA polymerase), $0.5 \mu \mathrm{M}$ Forward Primer (Supplementary Table S1, primer 1), $0.5 \mu \mathrm{M}$ Reverse Primer (Supplementary Table S1, primer 10), and SIRV2gp19 gene synthesis oligonucleotide template mixtures. Reactions were cycled in a PCR instrument $\left(98^{\circ} \mathrm{C}\right.$ $2 \mathrm{~min}$ followed by 25 cycles of $98^{\circ} \mathrm{C} 10 \mathrm{~s}, 65^{\circ} \mathrm{C} 15 \mathrm{~s}, 72^{\circ} \mathrm{C}$ $30 \mathrm{~s}$, followed by a final extension step at $72^{\circ} \mathrm{C}$ for $30 \mathrm{~s}$ ). A band corresponding to the SIRV2gp19 gene (405 bp) was gel purified. The SIRV2gp19 codon-optimized PCR product was cloned into expression vector pMAL-c4X (New England Biolabs) digested with XmnI to create a construct (pEPI) encoding an N-terminal Maltose Binding Protein (MBP)-SIRV2gp19 fusion protein. The sequence of plasmid pEPI was verified by DNA sequencing.

For MBP-SIRV2gp19 expression and purification, SHuffle ${ }^{\circledR}$ T7 Express E. coli was transformed with plasmid
pEPI. A 1 L SHuffle ${ }^{\circledR}$ T7 Express E. coli/pEPI culture was grown at $37^{\circ} \mathrm{C}$ to mid-log phase $\left(\mathrm{OD}_{600}=0.5\right)$, whereupon protein expression was induced by addition of $0.4 \mathrm{mM}$ IPTG. Cells were then incubated at $37^{\circ} \mathrm{C}$ for $5 \mathrm{~h}$, and cells were collected by centrifugation. The cell pellet was suspended in $0.2 \mathrm{~L}$ Buffer A (20 mM Tris- $\mathrm{HCl}, \mathrm{pH} 7.5,0.2 \mathrm{M}$ $\mathrm{NaCl}, 1 \mathrm{mM}$ EDTA) and lysed by sonication. Cell debris was removed by centrifugation and the supernatant was applied to a $15 \mathrm{~mL}$ amylose column. The column was washed with $0.15 \mathrm{~L}$ Buffer A. MBP-SIRV2 Hjr was eluted with $30 \mathrm{~mL}$ Buffer A containing $10 \mathrm{mM}$ maltose. MBPSIRV2gp19 purification was monitored by 4-20\% SDSPAGE analysis. Fractions containing MBP-SIRV2gp19 were pooled, dialysed against storage buffer $(0.1 \mathrm{M} \mathrm{KCl}$, $10 \mathrm{mM}$ Tris- $\mathrm{HCl}, \mathrm{pH} 7.4 @ 25^{\circ} \mathrm{C}, 1 \mathrm{mM}$ dithiothreitol, $0.1 \mathrm{mM}$ EDTA, $50 \%$ glycerol) and stored at $-20^{\circ} \mathrm{C}$.

SIRV2gp19 site-directed mutagenesis, expression, and purification

SIRV2gp19/D89A expression plasmid (plasmid: pEPJ) was constructed by PCR mutagenesis using Phusion SiteDirected Mutagenesis kit (New England Biolabs) using the following primers:

forward (D89A): pTCG CAT TGC TAT CGT TTG TGG CAA CG; reverse: pCCA GAG ATC TTC ATG CCT TCG ATT TCG.

Plasmids were screened for the correct D89A mutation by DNA sequencing. MBP-SIRV2gp19/D89A was expressed and purified as described above.

\section{SIRV2gp19 and SIRV2gp19/D89A nuclease activity}

Single- and double-stranded DNA endonuclease and exonuclease activities were monitored as described previously (Hirano et al. 2006). Quantities of MBP-SIRV2gp19 and MBP-SIRV2gp19/D89A (1, 0.5, 0.25, 0.125, 0.0625, 0.03125 pmol) were incubated with 0.5 pmol of circular single-stranded M13mp18 DNA (ssM13), 0.25 pmol linear double-stranded phiX/HaeIII DNA, or 0.25 pmol circular double-stranded DNA (pBR322 or double-stranded M13mp18) in $1 \times$ ThermoPol Buffer (20 mM Tris-HCl, $10 \mathrm{mM}\left(\mathrm{NH}_{4}\right)_{2} \mathrm{SO}_{4}, 10 \mathrm{mM} \mathrm{KCl}, 2 \mathrm{mM} \mathrm{MgSO}_{4}, 0.1 \%$ Triton $\mathrm{X}-100, \mathrm{pH} 8.8 @ 25^{\circ} \mathrm{C}$ ) in a $20 \mu \mathrm{L}$ reaction for $1 \mathrm{~h}$ at $55^{\circ} \mathrm{C}$. DNA products were separated by $0.7 \%$ agarose gel electrophoresis.

To confirm that SIRV2gp19 is an endonuclease, its activity was further characterized using a synthetic singlestranded oligonucleotide labeled on the $5^{\prime}$ or $3^{\prime}$ end with a 6-carboxyfluorescein (FAM)-label for detection (Supplemental Table S1). MBP-SIRV2gp19 $(0.2 \mu \mathrm{M})$ was incubated 
with $3^{\prime}$ or $5^{\prime}$ FAM-labeled oligonucleotide $(1 \mu \mathrm{M})$ in NEBuffer 4 (50 mM potassium acetate, $20 \mathrm{mM}$ Tris-acetate, pH $7.9 @ 25^{\circ} \mathrm{C}, 10 \mathrm{mM}$ magnesium acetate, and $1 \mathrm{mM}$ dithiothreitol) at $55^{\circ} \mathrm{C}$. E. coli exonuclease I $(0.05 \mu \mathrm{M})$, a single-stranded exonuclease, was incubated with $3^{\prime}$ or $5^{\prime}$ FAM-labeled oligonucleotide $(1 \mu \mathrm{M})$ in exonuclease I reaction buffer $\left(67 \mathrm{mM}\right.$ glycine- $\mathrm{KOH}, \mathrm{pH} 9.5 @ 25^{\circ} \mathrm{C}$, $6.7 \mathrm{mM} \mathrm{MgCl}_{2}$, and $10 \mathrm{mM} \mathrm{2-mercaptoethanol)} \mathrm{at} 37^{\circ} \mathrm{C}$. Single-stranded endonuclease, Mung Bean Nuclease $(0.3 \mu \mathrm{M})$, was incubated with $3^{\prime}$ or $5^{\prime}$ FAM-labeled oligonucleotide $(1 \mu \mathrm{M})$ in Mung Bean Nuclease buffer $(50 \mathrm{mM}$ sodium acetate, pH $5.0 @ 25^{\circ} \mathrm{C}, 30 \mathrm{mM} \mathrm{NaCl}$, and $1 \mathrm{mM}$ $\mathrm{ZnSO}_{4}$ ) at $30^{\circ} \mathrm{C}$. Reaction aliquots were sampled at the indicated times and reaction was halted by the addition of an equal volume of $10 \mathrm{mM}$ EDTA in formamide. Reaction products were separated by $15 \%$ denaturing PAGE and fluorescence was detected by a GE Typhoon scanner.

\section{Requirements for SIRV2gp19 nuclease activity}

To determine the effect of salt concentration, $\mathrm{pH}$ dependence and cation requirements on SIRV2gp19 activity, the nuclease assay as described above was repeated with single-stranded M13mp18 in varying reaction buffers. $\mathrm{NaCl}$ concentration was varied from 0 to $0.5 \mathrm{M}$ (in a buffer with $10 \mathrm{mM}$ Tris- $\mathrm{HCl}, \mathrm{pH} 7.0$ and $2 \mathrm{mM} \mathrm{MgCl}_{2}$ ). Tris- $\mathrm{HCl}$ or
Bis-Tris-propane $(10 \mathrm{mM})$ was used in the $\mathrm{pH}$ range of 5.0-10 (with $50 \mathrm{mM} \mathrm{NaCl}$ and $2 \mathrm{mM} \mathrm{MgCl}{ }_{2}$ ). $\mathrm{MgCl}_{2}$ was substituted by $2 \mathrm{mM} \mathrm{MnCl}_{2}, \mathrm{CoCl}_{2}, \mathrm{ZnSO}_{4}$, or $\mathrm{CaCl}_{2}$, in buffer containing $10 \mathrm{mM}$ Tris- $\mathrm{HCl}, \mathrm{pH} 7.0$ and $50 \mathrm{mM}$ $\mathrm{NaCl}$.

\section{Results}

SIRV2gp19 substrate specificity and requirements for cleavage activity

The similarity to the RecB nuclease superfamily led us to test SIRV2gp19 nuclease activity on a panel of DNA substrates to determine substrate specificity. Circular double-stranded M13mp18 DNA and linear double-stranded phiX174/HaeIII DNA were not substrates for SIRV2gp19 cleavage (Fig. 1a, b). SIRV2gp19 cleaved circular singlestranded M13mp18 DNA into smaller disperse fragments, appearing as a smear rather than discrete fragments, suggesting that SIRV2gp19 has minimal sequence or structure specificity (Fig. 1c).

To confirm that SIRV2gp19 is a single-stranded endonuclease, activity on a single-stranded oligonucleotide was tested. Oligonucleotide degradation by SIRV2gp19 was compared to degradation by a single-strand $3^{\prime}-5^{\prime}$ single-stranded DNA. MBPSIRV2gp19 nuclease activity was measured by incubating MBP-SIRV2gp19 dilutions (lanes 1-5 1, 0.5, 0.25, 0.125, or $0.0625 \mathrm{pmol}$ ) with $1 \mu \mathrm{g}$ of a circular double-stranded M13mp18 RF I DNA, b linear double-stranded phiX/HaeIII DNA, or c circular singlestranded M13mp18 DNA in $1 \times$ ThermoPol Buffer for $1 \mathrm{~h}$ at $55^{\circ} \mathrm{C}$. SIRV2gp19/D89A was assayed for nuclease activity as described above with substrates d circular double-stranded pBR322 DNA, e linear doublestranded phiX/HaeIII DNA, or f circular single-stranded M13mp18 DNA. As a control, DNA was incubated in the absence of MBP-SIRV2gp19 or MBP-SIRV2/D89A (-).

Reaction products were separated by $0.7 \%$ agarose gel electrophoresis. The NEB $1 \mathrm{~kb}$ DNA ladder $(M)$ as a reference
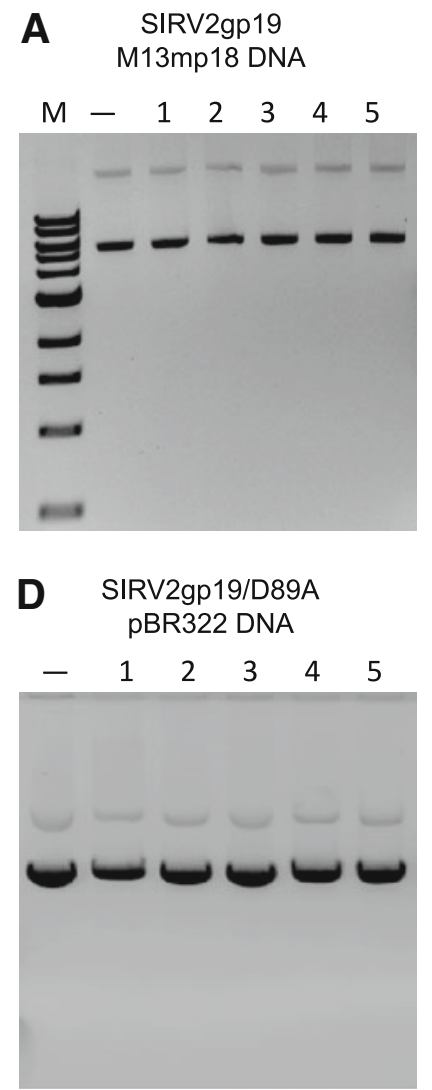

B SIRV2gp19
phiX/HaellI DNA
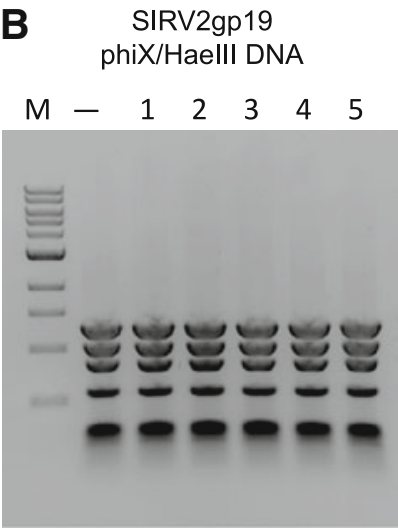

E
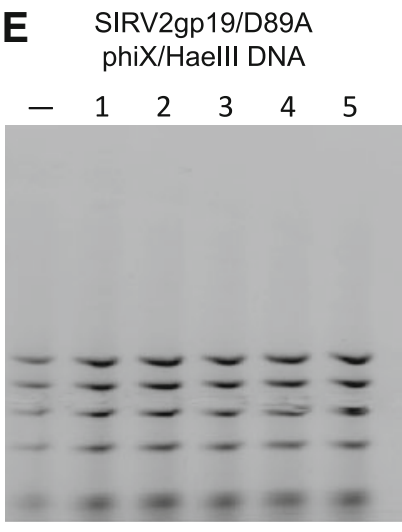
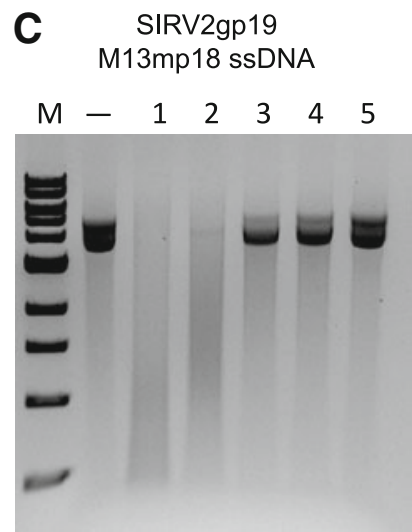

$\mathbf{F}$ SIRV2gp19/D89A M13mp18 ssDNA

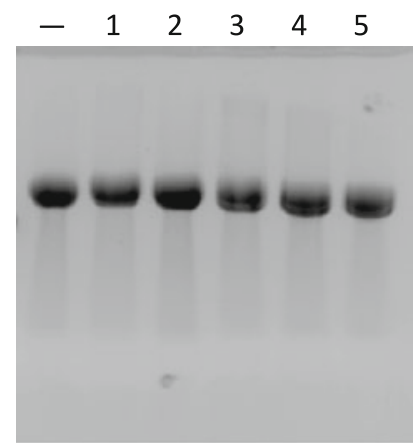


exonuclease (E. coli exonuclease I) and a single-strand endonuclease (Mung Bean Nuclease) (Fig. 2). As previously shown (Brody et al. 1986), E. coli exonuclease I processively degrades single-stranded oligonucleotides in the $3^{\prime}-5^{\prime}$ direction releasing dNMPs (Fig. 2). Mung Bean Nuclease degrades single-strand oligonucleotides by cleavage at internal sites (Fig. 2) (Johnson and Laskowski 1968). Similar to Mung Bean Nuclease, SIRV2gp19 degrades single-strand oligonucleotides by cleavage at internal sites (Fig. 2), confirming that SIRV2gp19 is a single-strand specific DNA endonuclease.

Requirements for SIRV2gp19 single-stranded DNA cleavage

The reaction conditions for SIRV2gp19 were investigated using single-stranded M13mp18 DNA as a substrate. Despite the acidic growth environment, the internal $\mathrm{pH}$ of host Sulfolobus islandicus is neutral. Therefore, it was of interest to determine whether SIRV2gp19 had a pH optimum mimicking the neutral intracellular $\mathrm{pH}$ or the acidic extracellular environment. SIRV2gp19 activity optimum reflects the host intracellular $\mathrm{pH}$ and cleaves cruciform DNA with a broad pH range between $\mathrm{pH} 7.0$ and 10.0, with inhibition occurring below pH 7.0 (Table 1). Similar to previous studies (Kushner et al. 1971), $\mathrm{MgCl}_{2}$ is a required cofactor for SIRV2gp19 cleavage and cannot be substituted by $\mathrm{MnCl}_{2}, \mathrm{CaCl}_{2}, \mathrm{ZnSO}_{4}$ or $\mathrm{CoCl}_{2}$ (Table 1).
$\mathrm{NaCl}$ is not required for SIRV2gp19 activity and inhibits activity at higher concentrations of $\mathrm{NaCl}(>100 \mathrm{mM})$ (Table 1).

SIRV2gp19/D89A and its biochemical characterization

Previous studies identified a conserved aspartic acid in Motif II of the RecB nuclease superfamily that coordinates $\mathrm{a} \mathrm{Mg}^{2+}$ required for nuclease activity (Singleton et al. 2004; Wang et al. 2000; Yu et al. 1998). To test if this conserved Motif II aspartic acid is also essential for SIRV2gp19 activity, Asp89 was mutated to alanine (SIRV2gp19/D89A). SIRV2gp19/D89A nuclease activity was completely abolished on M13mp18 circular singlestranded DNA as well as double-stranded DNA substrates (Fig. 1).

\section{Discussion}

SIRV2gp19, previously annotated as a hypothetical RecB nuclease, is a single-stranded specific DNA endonuclease. Mutagenesis of conserved SIRV2gp19 Motif II aspartate to alanine (D89A) abolishes nuclease activity, presumably by disrupting $\mathrm{Mg}^{2+}$ coordination in the active site. As little sequence or structure specificity was observed with the SIRV2gp19 nuclease, it could act with other components to direct nuclease activity like the related archaeal cas 4

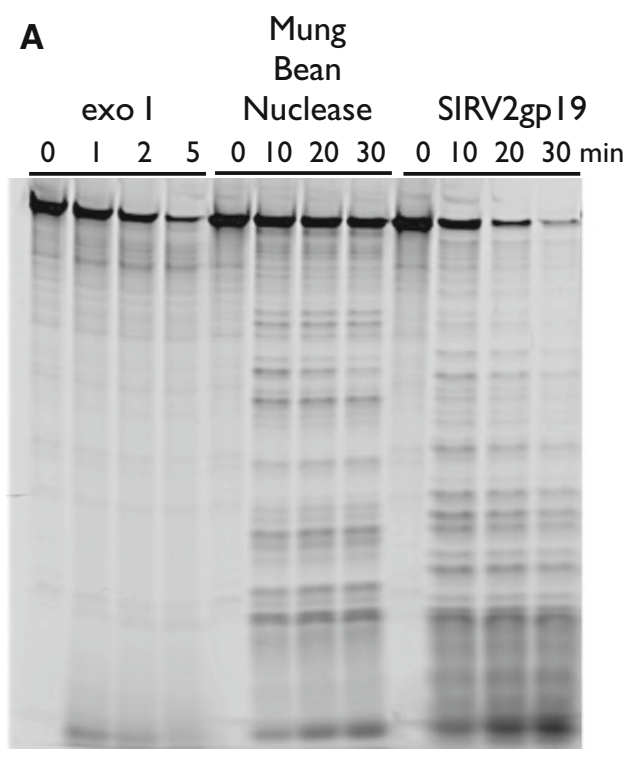

Fig. 2 SIRV2gp19 is a single-strand specific endonuclease. Nuclease activity was characterized using a synthetic single-stranded oligonucleotide labeled on the a $5^{\prime}$ or $\mathbf{b} 3^{\prime}$ end with a fluorescent FAM-label for detection. MBP-SIRV2gp19 $(0.2 \mu \mathrm{M})$ was incubated with $\mathbf{a} 5^{\prime}$ or b $3^{\prime}$ FAM-labeled oligonucleotide $(1 \mu \mathrm{M})$ in NEBuffer 4 at $55^{\circ} \mathrm{C}$. E. coli exonuclease I (exo I) $(0.05 \mu \mathrm{M})$ was incubated with a $5^{\prime}$ or b $3^{\prime}$ FAM-labeled oligonucleotide $(1 \mu \mathrm{M})$ in exonuclease I

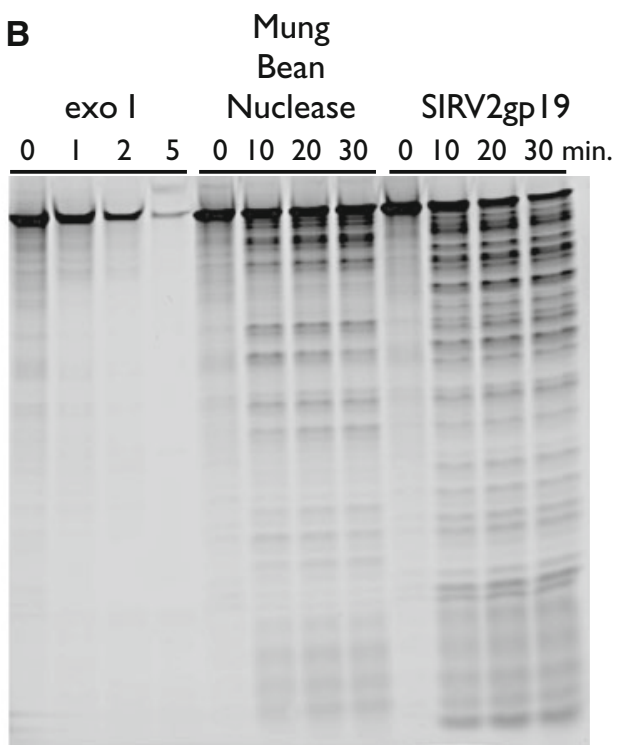

reaction buffer at $37^{\circ} \mathrm{C}$. Mung Bean Nuclease $(0.3 \mu \mathrm{M})$ was incubated with a $5^{\prime}$ or b $3^{\prime}$ FAM-labeled oligonucleotide $(1 \mu \mathrm{M})$ in Mung Bean Nuclease buffer at $30^{\circ} \mathrm{C}$. Reaction aliquots were sampled at the indicated times and reaction was halted by the addition of EDTA $(10 \mathrm{mM})$ in formamide. Reaction products were separated by $15 \%$ denaturing PAGE and fluorescence detected by a GE Typhoon scanner 
Table 1 Minimal requirements for SIRV2gp19 activity

\begin{tabular}{llllll}
\hline $\begin{array}{l}{[\mathrm{NaCl}]} \\
(\mathrm{mM})\end{array}$ & \begin{tabular}{l} 
SIRV2gp19 $_{\text {activity }^{\mathrm{a}}}$ \\
\hline 0
\end{tabular} $\mathrm{pH}^{+}$ & $\begin{array}{l}\text { SIRV2gp19 } \\
\text { activity }^{\mathrm{a}}\end{array}$ & $\begin{array}{l}\text { Cation } \\
(2 \mathrm{mM})\end{array}$ & $\begin{array}{l}\text { SIRV2gp } \\
\text { activity }^{\mathrm{a}}\end{array}$ \\
50 & + & 6 & - & $\mathrm{MgCl}_{2}$ & + \\
100 & + & 7 & + & $\mathrm{MnCl}_{2}$ & - \\
200 & - & 8 & + & $\mathrm{ZnSO}_{4}$ & - \\
300 & - & 9 & + & $\mathrm{CoCl}_{2}$ & - \\
400 & - & 10 & + & $\mathrm{CaCl}_{2}$ & - \\
500 & - & & & & \\
\hline
\end{tabular}

${ }^{\text {a }}$ Single-stranded endonuclease activity $(+)$ or no detectible activity $(-)$

\section{A}

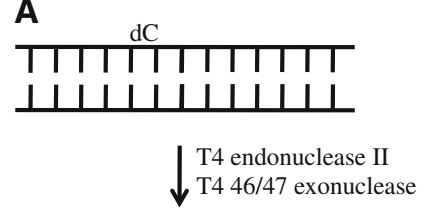

B

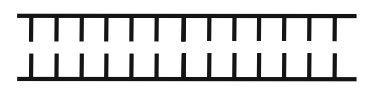

$\downarrow$ nuclease(s)
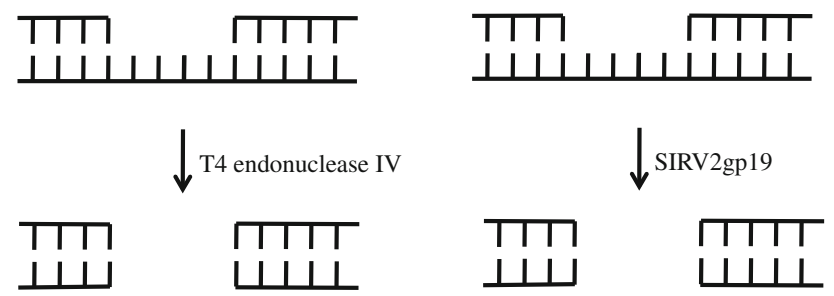

and cleaves single-stranded gapped regions to create doublestranded breaks, leading to a collapse of the host genome (Parson and Snustad 1975).

Consistent with a model of host chromosome degradation (Bize et al. 2009), one might expect SIRV2 to encode double-strand specific nucleases akin to T4 endonuclease II and 46/47 exonucleases to create single-stranded gaps in the host chromosome. Such an endonuclease has not yet been identified in SIRV2. However, SIRV2gp19, a singlestrand endonuclease, could catalyze the second step of the degradation process since it could cleave single-stranded gapped regions similar to T4 endonuclease IV (Fig. 3). Therefore, in spite of differences in hosts and environments, mechanisms for core viral processes such as host chromosome degradation could converge. Assigning functions to additional proteins annotated as hypothetical will be essential to more completely understand SIRV2 core functions.

Open Access This article is distributed under the terms of the Creative Commons Attribution Noncommercial License which permits any noncommercial use, distribution, and reproduction in any medium, provided the original author(s) and source are credited.

\section{References}

Aravind L, Makarova KS, Koonin EV (2000) Survey and summary: holliday junction resolvases and related nucleases: identification of new families, phyletic distribution and evolutionary trajectories. Nucleic Acids Res 28(18):3417-3432

Fig. 3 A model of SIRV2gp19 host chromosome during SIRV2 infection. Bacteriophage T4 or SIRV2 infection triggers an enzymatic cascade that degrades of the host chromosome (Bize et al. 2009; Parson and Snustad 1975). a T4 endonuclease II creates nicks in dCMP regions of the host chromosome. T4 46/47 exonuclease removes mononucleotides at gaps to create single-stranded DNA regions. Then T4 endonuclease IV cleaves these single-stranded gaps to fragment DNA. b If SIRV2 degrades its host chromosome by a similar mechanism as bacteriophage $\mathrm{T} 4$, then a predicted nuclease could first create single-stranded gaps in the host chromosome. This nuclease has not been identified. Then SIRV2gp19, a single-stranded endonuclease, could cleave single-stranded gaps and fragment the host chromosome

nuclease involved in CRISPR processing (Haft et al. 2005; Jansen et al. 2002). Alternatively, SIRV2gp19 could act as a broad spectrum nuclease, presumably to degrade DNA. Broad degradative function has been observed in the metabolism of other bacteriophages, e.g., bacteriophage T4 (Parson and Snustad 1975). Bacteriophage T4 degrades host chromosomal DNA by a combination of several nucleases (Fig. 3). First, a double-strand specific endonuclease (T4 endonuclease II) makes nicks in double-stranded host DNA. Then 46/47 exonuclease catalyzes the removal of mononucleotides from the nicks to expose gapped, single-stranded DNA regions. Finally, a singlestranded endonuclease (T4 endonuclease IV) recognizes
Bize A, Karlsson EA, Ekefjard K, Quax TE, Pina M, Prevost MC, Forterre P, Tenaillon O, Bernander R, Prangishvili D (2009) A unique virus release mechanism in the Archaea. Proc Natl Acad Sci USA 106(27):11306-11311

Blum H, Zillig W, Mallok S, Domdey H, Prangishvili D (2001) The genome of the archaeal virus SIRV1 has features in common with genomes of eukaryal viruses. Virology 281(1):6-9

Brody RS, Doherty KG, Zimmerman PD (1986) Processivity and kinetics of the reaction of exonuclease I from Escherichia coli with polydeoxyribonucleotides. J Biol Chem 261(16):7136-7143

Czar MJ, Anderson JC, Bader JS, Peccoud J (2009) Gene synthesis demystified. Trends Biotechnol 27(2):63-72

Dillingham MS, Kowalczykowski SC (2008) RecBCD enzyme and the repair of double-stranded DNA breaks. Microbiol Mol Biol Rev 72(4):642-671

Haft DH, Selengut J, Mongodin EF, Nelson KE (2005) A guild of 45 CRISPR-associated (Cas) protein families and multiple CRISPR/ Cas subtypes exist in prokaryotic genomes. PLoS Comput Biol 1(6): 60

Hirano N, Ohshima H, Takahashi H (2006) Biochemical analysis of the substrate specificity and sequence preference of endonuclease IV from bacteriophage $\mathrm{T} 4$, a $\mathrm{dC}$-specific endonuclease implicated in restriction of dC-substituted T4 DNA synthesis. Nucleic Acids Res 34(17):4743-4751

Jansen R, Embden JD, Gaastra W, Schouls LM (2002) Identification of genes that are associated with DNA repeats in prokaryotes. Mol Microbiol 43(6): 1565-1575

Johnson PH, Laskowski M Sr (1968) Sugar-unspecific mung bean nuclease I. J Biol Chem 243(12):3421-3424 
Kessler A, Brinkman AB, van der Oost J, Prangishvili D (2004) Transcription of the rod-shaped viruses SIRV1 and SIRV2 of the hyperthermophilic archaeon Sulfolobus. J Bacteriol 186(22): $7745-7753$

Kushner SR, Nagaishi H, Templin A, Clark AJ (1971) Genetic recombination in Escherichia coli: the role of exonuclease I. Proc Natl Acad Sci USA 68(4):824-827

Parson KA, Snustad DP (1975) Host DNA degradation after infection of Escherichia coli with bacteriophage T4: dependence of the alternate pathway of degradation which occurs in the absence of both T4 endonuclease II and nuclear disruption on T4 endonuclease IV. J Virol 15(1):221-224

Peng X, Blum H, She Q, Mallok S, Brugger K, Garrett RA, Zillig W, Prangishvili D (2001) Sequences and replication of genomes of the archaeal rudiviruses SIRV1 and SIRV2: relationships to the archaeal lipothrixvirus SIFV and some eukaryal viruses. Virology 291(2):226-234
Prangishvili D, Forterre P, Garrett RA (2006a) Viruses of the Archaea: a unifying view. Nat Rev Microbiol 4(11):837-848

Prangishvili D, Garrett RA, Koonin EV (2006b) Evolutionary genomics of archaeal viruses: unique viral genomes in the third domain of life. Virus Res 117(1):52-67

Singleton MR, Dillingham MS, Gaudier M, Kowalczykowski SC, Wigley DB (2004) Crystal structure of RecBCD enzyme reveals a machine for processing DNA breaks. Nature 432(7014): 187-193

Wang J, Chen R, Julin DA (2000) A single nuclease active site of the Escherichia coli RecBCD enzyme catalyzes single-stranded DNA degradation in both directions. J Biol Chem 275(1): 507-513

Yu M, Souaya J, Julin DA (1998) Identification of the nuclease active site in the multifunctional RecBCD enzyme by creation of a chimeric enzyme. J Mol Biol 283(4):797-808 